\title{
Combining Glyphosate With Burning or Mowing Improves Control of Yellow Bluestem (Bothriochloa ischaemum)
}

\author{
Scott Robertson, ${ }^{1}$ Karen R. Hickman, ${ }^{2}$ Keith R. Harmoney, ${ }^{3}$ and David M. Leslie, Jr. ${ }^{4}$ \\ Authors are ${ }^{1}$ Research Assistant and ${ }^{2}$ Professor, Department of Natural Resource Ecology and Management, Oklahoma State University, Stillwater, OK \\ 74078, USA; ${ }^{3}$ Range Scientist, Kansas State University Agricultural Research Center, Hays, KS 67601, USA; and ${ }^{4}$ Unit Leader, US Geological Survey, \\ Oklahoma Cooperative Fish and Wildlife Research Unit, Oklahoma State University, Stillwater, OK 74078, USA.
}

\begin{abstract}
The invasive yellow bluestem (Bothriochloa ischaemum [L.] Keng) threatens native biodiversity, and its control is of interest to land managers involved in restoration of invaded grasslands. We used single, double, and triple applications of glyphosate (2.125 $\mathrm{kg}$ ai $\cdot \mathrm{ha}^{-1} \cdot$ application $^{-1}$ ) over the course of one growing season in combinations at different timings (early, middle, late season) with and without a mechanical treatment of mowing or burning to determine the most effective control method. One year after treatment, burning and mowing prior to a mid-season single or double early, middle, and/or late season herbicide application resulted in a similar level of control of yellow bluestem relative to a triple herbicide application, all of which had greater control relative to herbicide treatment alone. Reproductive tiller density and visual obstruction increased 2 yr after treatment with two herbicide treatments applied either early and middle season or early and late season, but it was prevented with burning and mowing prior to herbicide application. With the exception of three herbicide applications, combining burning or mowing with herbicide applications provided more effective control of yellow bluestem than any individual herbicide applications. Burning or mowing likely improves glyphosate effectiveness by altering the invasive grass structure so that plants are clear of standing dead and have shorter, active regrowth to enhance herbicide effectiveness. During restoration projects requiring control of invasive yellow bluestem, an effective management option is a combination of mechanical and chemical control.
\end{abstract}

Key Words: burning, exotic species, integrated pest management, King Ranch bluestem, Old World bluestem, restoration

\section{INTRODUCTION}

Yellow bluestem [Bothriochloa ischaemum (L.) Keng] is a Eurasian perennial, warm-season grass introduced into the central and southern Great Plains. In the 1980s and 1990s, it was commonly planted in monocultures for forage/hay production and soil stabilization in Conservation Reserve Program plantings and roadsides because it was easily established and tolerated drought and heavy grazing (Coyne and Bradford 1986). Recent research has shown that monocultures of yellow bluestem reduce diversity and abundance of native plant communities (Gabbard and Fowler 2007), grassland birds and arthropods (Hickman et al. 2007), small mammals (Sammon and Wilkins 2005), and swift fox (Vulpes velox) (Kamler et al. 2003). Undesirable effects of yellow

\footnotetext{
Research was funded by State Wildlife Grant Project T-36-P of the Oklahoma Department of Wildlife Conservation and Oklahoma State University and the National Research Initiative of the USDA Cooperative State Research, Education and Extension Service, grant number 2006-35320-17476 and administered by the Oklahoma Cooperative Fish and Wildlife Research Unit (Oklahoma State University, Oklahoma Department of Wildlife Conservation, US Geological Survey, US Fish and Wildlife Service, and Wildlife Management Institute cooperating).

Any use of trade, firm, or product names is for description purposes only and does not imply endorsement by the US Government.

Correspondence: Karen R. Hickman, Department of Natural Resource Ecology and Management, Oklahoma State University, Stillwater, OK 74078, USA. Email: karen. hickman@okstate.edu
}

Manuscript received 16 October 2011; manuscript accepted 15 February 2013.

(c) 2013 The Society for Range Management bluestem invasion have prompted land managers to seek methods for controlling it and restoring native vegetation.

Control of mature yellow bluestem stands has met with variable success. Glyphosate applied at a rate of $2.125 \mathrm{~kg}$ ai $\cdot \mathrm{ha}^{-1}$ can be the most cost effective herbicide for controlling yellow bluestem, with single spring applications providing $43 \%$ control by the end of the first year. Two glyphosate applications $(1.14$ $\mathrm{kg} \cdot \mathrm{ha}^{-1}$ applied at each application) during a single growing season increased control to $90 \%$ after the first frost (Harmoney et al. 2004, 2007). Independent effects of mowing, burning, and glyphosate showed that mowing alone did not reduce cover of yellow bluestem, relative to nontreated areas, 1 yr posttreatment by $>50 \%$ (Simmons et al. 2007), a level necessary for restoration of invaded areas (Packard and Mutel 2005).

A study with other invasive/weedy species had greater control when mechanical and chemical treatments were combined rather than applied individually (Renz and DiTomaso 2004). Therefore, our objective was to determine the most effective treatment for controlling yellow bluestem by assessing effectiveness of herbicide timing, application number, and combinations of mechanical (mowing and burning) and herbicide treatments.

\section{METHODS}

Research was conducted at the Marvin Klemme Range Research Station (lat $35^{\circ} 22^{\prime} \mathrm{N}$, long $99^{\circ} 04^{\prime} \mathrm{W}$ ) in western Oklahoma, USA, with approximately $76 \mathrm{~cm}$ of precipitation 
annually and an average summer high temperature of $34.2^{\circ} \mathrm{C}$ (Brock et al. 1995). We worked in a 6.5 -ha field previously cultivated for wheat (Triticum aestivum L.) and converted to yellow bluestem in 1989. Annual precipitation for 2006, 2007, and 2008 was $710 \mathrm{~mm}, 890 \mathrm{~mm}$, and $810 \mathrm{~mm}$, respectively, with between $45 \%$ and $65 \%$ of the annual precipitation received between the months of February and July the year prior to (2006) and during the study period (2007 and 2008).

In 2007, single, multiple, and combined treatments of herbicide, burning, and mowing were applied in an factorial experiment using a randomized block design (four replicates), building on previous research (McWhorter and Hanks 1993; Harmoney et al. 2004, 2007; Simmons et al. 2007). Treatments were stratified so that all burned, mowed, and control (no treatment) plots were grouped together within each replication. Eleven combinations of herbicide $(\mathrm{H})$, burning (B), and mowing $(\mathrm{M})$ were applied to $10 \times 10 \mathrm{~m}$ plots. In 2007 , single, double, and triple applications of herbicide were applied at three times during the growing season: early (subscript $\mathrm{E}=18$ May), middle (subscript $\mathrm{M}=2$ August), and late (subscript $\mathrm{L}=1$ September). The single herbicide-only treatment $\left(\mathrm{H}_{\mathrm{M}}\right)$ was applied on 2 August. The two treatments involving double herbicide applications were applied at the early and middle timings $\left(\mathrm{H}_{\mathrm{E}}+\mathrm{H}_{\mathrm{M}}\right)$ or at the early and late timings $\left(\mathrm{H}_{\mathrm{E}}+\mathrm{H}_{\mathrm{L}}\right)$. The triple treatment applied herbicide at all three timings $\left(\mathrm{H}_{\mathrm{E}}+\mathrm{H}_{\mathrm{M}}+\mathrm{H}_{\mathrm{L}}\right)$. Burning for the treatment involving a burn in addition to a single herbicide application treatment $\left(\mathrm{B}_{\mathrm{E}}+\mathrm{H}_{\mathrm{E}}\right)$ occurred early (18 May) in the season and was followed by an herbicide application 4-5 wk later when yellow bluestem had regrown to the 4-5 leaf stage. The two treatments involving a burn plus a double herbicide application occurred at two different timing combinations: early (18 May) burn followed by an herbicide application (28 June) with an additional late season herbicide application (1 September) $\left(\mathrm{B}_{\mathrm{E}}+\mathrm{H}_{\mathrm{E}}+\mathrm{H}_{\mathrm{L}}\right)$ and an early (18 May) herbicide application and middle burn (25 July) followed by a second herbicide application in the middle of the season (30 August) $\left(\mathrm{H}_{\mathrm{E}}+\mathrm{B}_{\mathrm{M}}+\mathrm{H}_{\mathrm{M}}\right)$. The treatment timing of the combined mowing and herbicide treatments was the same as the combined burn and herbicide treatments except that mowing was substituted for burning $\left(\mathrm{M}_{\mathrm{E}}+\mathrm{H}_{\mathrm{E}}\right.$, $\mathrm{M}_{\mathrm{E}}+\mathrm{H}_{\mathrm{E}}+\mathrm{H}_{\mathrm{L}}$, and $\left.\mathrm{H}_{\mathrm{E}}+\mathrm{M}_{\mathrm{M}}+\mathrm{H}_{\mathrm{M}}\right)$.

Glyphosate (Roundup WeatherMAX, Monsanto, St. Louis, MO) was applied at $2.125 \mathrm{~kg} \mathrm{ai} \cdot \mathrm{ha}^{-1}$. application ${ }^{-1}$ (mixed with $0.232 \mathrm{~kg}$ of ammonium sulfate) using a R\&D EXD-203s (R\&D Sprayers, Opelousa, LA) bicycle sprayer with six 11002 AirMix $110^{\circ}$ fan nozzles (Kremlin-Rexson, Plymouth, MI) spaced $45.7 \mathrm{~cm}$ apart and positioned approximately $20-25 \mathrm{~cm}$ above the vegetation. All herbicide applications were conducted during favorable weather conditions to prevent drift and limit overspray. All burning occurred in favorable weather conditions (e.g., $<16 \mathrm{~km} \cdot \mathrm{h}^{-1}$ wind speed) using a combination of ring and strip-head fire techniques (Weir 2009).

Vegetation sampling methods were modified from Harmoney et al. (2004). A $1 \times 1 \mathrm{~m}$ quadrat, divided into 100 subquadrats, was used to determine frequency of yellow bluestem crowns by counting the number of subquadrats that contained living crowns (three frequency readings per plot during each sampling period). Basal tiller density was determined by counting all tillers in five randomly selected subquadrats for each plot. Tiller density was recorded three times in every plot. A $0.5 \times 0.5 \mathrm{~m}$ frame was used to quantify reproductive tiller density and percent cover of yellow bluestem with three readings of each measurement per plot. Percent cover of yellow bluestem was estimated visually using a modified Daubenmire approach (Daubenmire 1959). Vegetation structural measurements were recorded using a digital visual obstruction technique (Limb et al. 2007). In February 2008, all plots were burned to remove standing dead litter. Vegetation was sampled at the end of the growing season in 2007 and 2008. The majority of yellow bluestem originated from established crowns that survived treatment and not from seeds (S. Robertson, unpublished data, 2007 and 2008).

Data were analyzed using an analysis of variance procedure, with a least significant difference post hoc test (SAS Institute 2003) to assess differences among treatments for frequency of live crowns, yellow bluestem cover, basal tillers, reproductive tillers, and vegetative structure. Significance was set at $P<0.05$, and data were analyzed separately for 2007 and 2008.

\section{RESULTS AND DISCUSSION}

\section{End of First Year (2007)}

All treatments significantly reduced yellow bluestem cover compared with the untreated control (Fig. 1A). The triple herbicide treatment $\left(\mathrm{H}_{\mathrm{E}}+\mathrm{H}_{\mathrm{M}}+\mathrm{H}_{\mathrm{L}}\right)$, both double-herbicide treatments $\left(\mathrm{H}_{\mathrm{E}}+\mathrm{H}_{\mathrm{M}}\right.$ and $\left.\mathrm{H}_{\mathrm{E}}+\mathrm{H}_{\mathrm{L}}\right)$, and all double herbicide treatments with a mow or burn $\left(\mathrm{M}_{\mathrm{E}}+\mathrm{H}_{\mathrm{E}}+\mathrm{H}_{\mathrm{L}}, \mathrm{H}_{\mathrm{E}}+\mathrm{M}_{\mathrm{M}}+\mathrm{H}_{\mathrm{M}}\right.$, $\mathrm{B}_{\mathrm{E}}+\mathrm{H}_{\mathrm{E}}+\mathrm{H}_{\mathrm{L}}$, and $\left.\mathrm{H}_{\mathrm{E}}+\mathrm{B}_{\mathrm{M}}+\mathrm{H}_{\mathrm{M}}\right)$ had the lowest cover of yellow bluestem. Harmoney (2007) also found that single glyphosate applications were not as effective as multiple applications; however, our mow-single-herbicide and burnsingle-herbicide treatments significantly reduced frequency and basal tiller density of yellow bluestem compared with the single-herbicide treatment (Figs. 1B and 1C). All treatments except the single-herbicide treatment reduced number of basal tillers relative to the control (Fig. 1C). Three treatments had no reproductive tillers at the end of the first year: triple herbicide, double herbicide applications early and late in the season, and burn-early-double-herbicide (Fig. 1D).

Visual obstruction was reduced relative to the control in all treatments except the single herbicide application and double herbicide applications early and late in the season $\left(\mathrm{H}_{\mathrm{E}}+\mathrm{H}_{\mathrm{L}}\right)$. Interestingly, the treatment involving two (double) herbicide applications early and late in the season had $57 \%$ greater visual obstruction relative to the other double $\left(\mathrm{H}_{\mathrm{E}}+\mathrm{H}_{\mathrm{M}}\right)$ and triple $\left(\mathrm{H}_{\mathrm{E}}+\mathrm{H}_{\mathrm{M}}+\mathrm{H}_{\mathrm{L}}\right)$ herbicide treatments (Fig. 1E). Overall, six treatments had $<5 \%$ cover and 10 crowns $\cdot \mathrm{m}^{2}$ at the end of the first year.

\section{End of Second Year (2008)}

After $2 \mathrm{yr}$, only the triple herbicide treatment $\left(\mathrm{H}_{\mathrm{E}}+\mathrm{H}_{\mathrm{M}}+\mathrm{H}_{\mathrm{L}}\right)$ and the early herbicide following by burning and an additional late season herbicide application treatment $\left(\mathrm{H}_{E}+\mathrm{B}_{\mathrm{M}}+\mathrm{H}_{\mathrm{L}}\right)$ maintained a similar reduction in cover and frequency of yellow bluestem as at the end of 2007 (Figs. 2A and 2B). Both double herbicide only treatments $\left(\mathrm{H}_{\mathrm{E}}+\mathrm{H}_{\mathrm{M}}\right.$ and $\left.\mathrm{H}_{\mathrm{E}}+\mathrm{H}_{\mathrm{L}}\right)$ had less cover of yellow bluestem compared with the one herbicide 

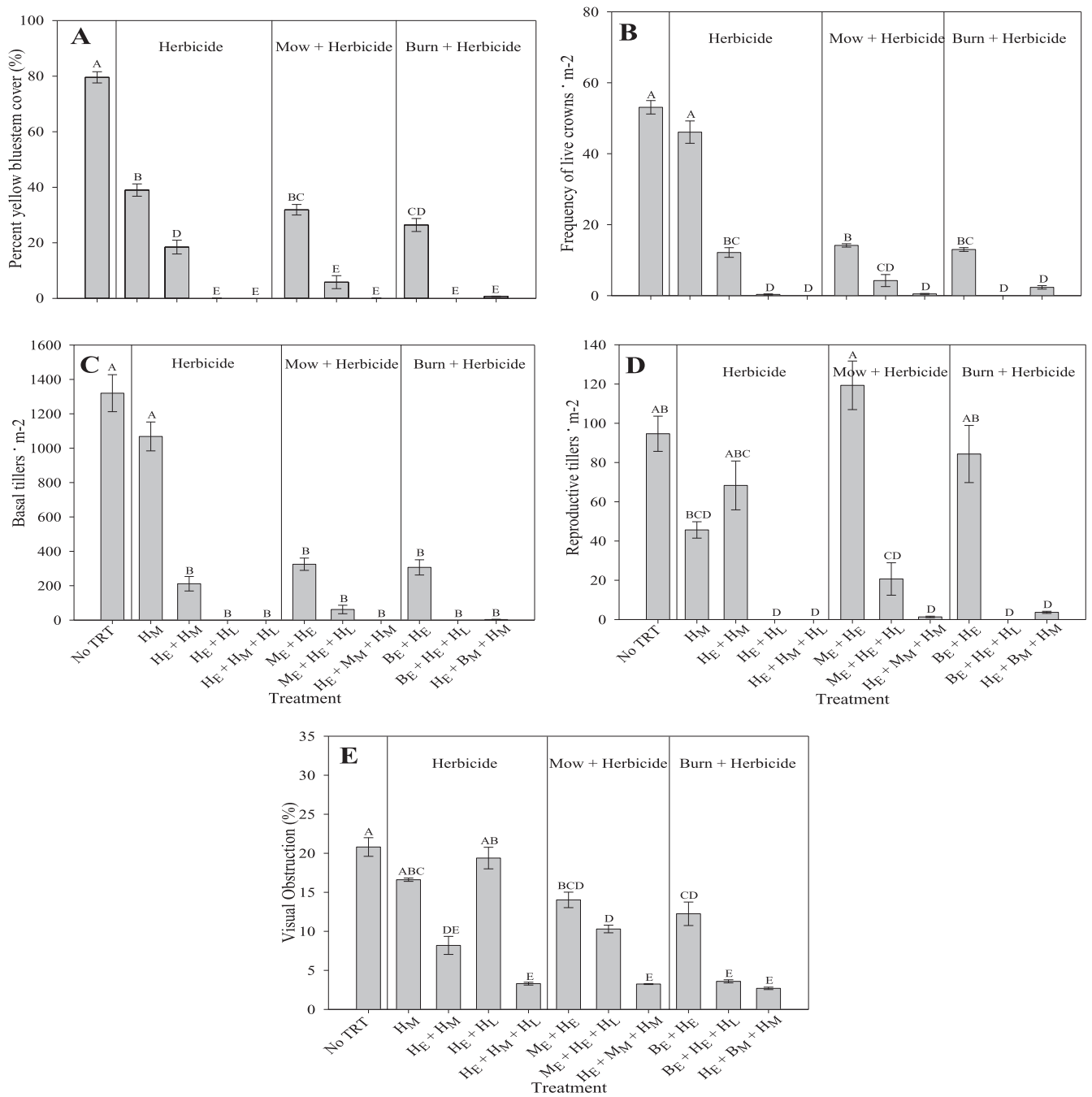

Figure 1. Yellow bluestem A, percent cover; B, frequency of live crowns (per $\left.\mathrm{m}^{2}\right)$; C, basal tiller density $\left(\right.$ per $\left.\mathrm{m}^{2}\right)$; D, reproductive tiller density $\left(\right.$ per $\left.\mathrm{m}^{2}\right)$; and $\mathbf{E}$, visual obstruction, all at end of season 2007 (mean \pm SE). Different letters indicate significant difference at the $P<0.05$. Eleven different treatment combinations involving herbicide $(\mathrm{H})$, burning $(\mathrm{B})$, and mowing $(\mathrm{M})$ were applied in 2007 either once, twice, or three times during the growing season: early (subscript $\mathrm{E}=18$ May), middle ( $\mathrm{M}=2$ August), late ( $\mathrm{L}=1$ September).

application $\left(\mathrm{H}_{\mathrm{M}}\right)$ without a mechanical treatment. Both double herbicide only treatments $\left(\mathrm{H}_{\mathrm{E}}+\mathrm{H}_{\mathrm{M}}\right.$ and $\left.\mathrm{H}_{\mathrm{E}}+\mathrm{H}_{\mathrm{L}}\right)$ reduced cover of yellow bluestem $32-51 \%$ compared with the control. Simmons et al. (2007) also reported that two applications of glyphosate reduced cover of yellow bluestem by $50 \%$; they also tested mowing, burning, and glyphosate (one or two applications) independently and concluded that two mowing events had no effect on cover but that a growing season burn reduced cover by $30 \%$ one year after treatment. In our study, both mowing and burning in combination with two herbicide applications $\left(\mathrm{M}_{\mathrm{E}}+\mathrm{H}_{\mathrm{E}}+\mathrm{H}_{\mathrm{L}}, \mathrm{H}_{\mathrm{E}}+\mathrm{M}_{\mathrm{M}}+\mathrm{H}_{\mathrm{M}}, \mathrm{B}_{\mathrm{E}}+\mathrm{H}_{\mathrm{E}}+\mathrm{H}_{\mathrm{L}}\right.$, and $\mathrm{H}_{\mathrm{E}}+\mathrm{B}_{\mathrm{M}}+\mathrm{H}_{\mathrm{M}}$ ) reduced cover of yellow bluestem by $77-98 \%$. Combining two herbicide applications with a single pretreatment mow or burn reduced yellow bluestem cover compared with only two herbicide applications applied without a mechanical treatment. Mowing or burning in combination with two herbicide applications had similar yellow bluestem cover as the triple herbicide application. Two treatments had $<75$ basal tillers $\cdot \mathrm{m}^{-2}$ : the triple herbicide application $\left(\mathrm{H}_{\mathrm{E}}+\mathrm{H}_{\mathrm{M}}+\mathrm{H}_{\mathrm{L}}\right)$ and the early herbicide followed by burning and an additional herbicide application $\left(\mathrm{H}_{\mathrm{E}}+\mathrm{B}_{\mathrm{M}}+\mathrm{H}_{\mathrm{M}}\right.$; Fig. 2C).

Given concerns over the unintentional consequences of glyphosate use on amphibians (Relyea 2012), limiting the number of herbicide applications could be a consideration in restoration plans. Therefore, combining glyphosate applications with a pretreatment mowing or burning provides similar overall control of yellow bluestem (e.g., reduction of cover, frequency, basal tillers, reproductive tillers, and visual obstruction), relative to three herbicide applications. This is likely because early mechanical treatment removed standing dead material, altered canopy structure, and improved herbicide absorption by leaves. Mowing and burning clearly decreased the standing dead, which can intercept the herbicide and reduce its effectiveness by decreasing contact with living leaf tissue (Wolf et al. 2000; DiTomaso et al. 2006). Mowing or burning also altered canopy structure by removing upper vegetation and exposing new basal regrowth (Renz and DiTomaso 2004), which might be less detrimental to nontarget organisms than an additional herbicide application. 

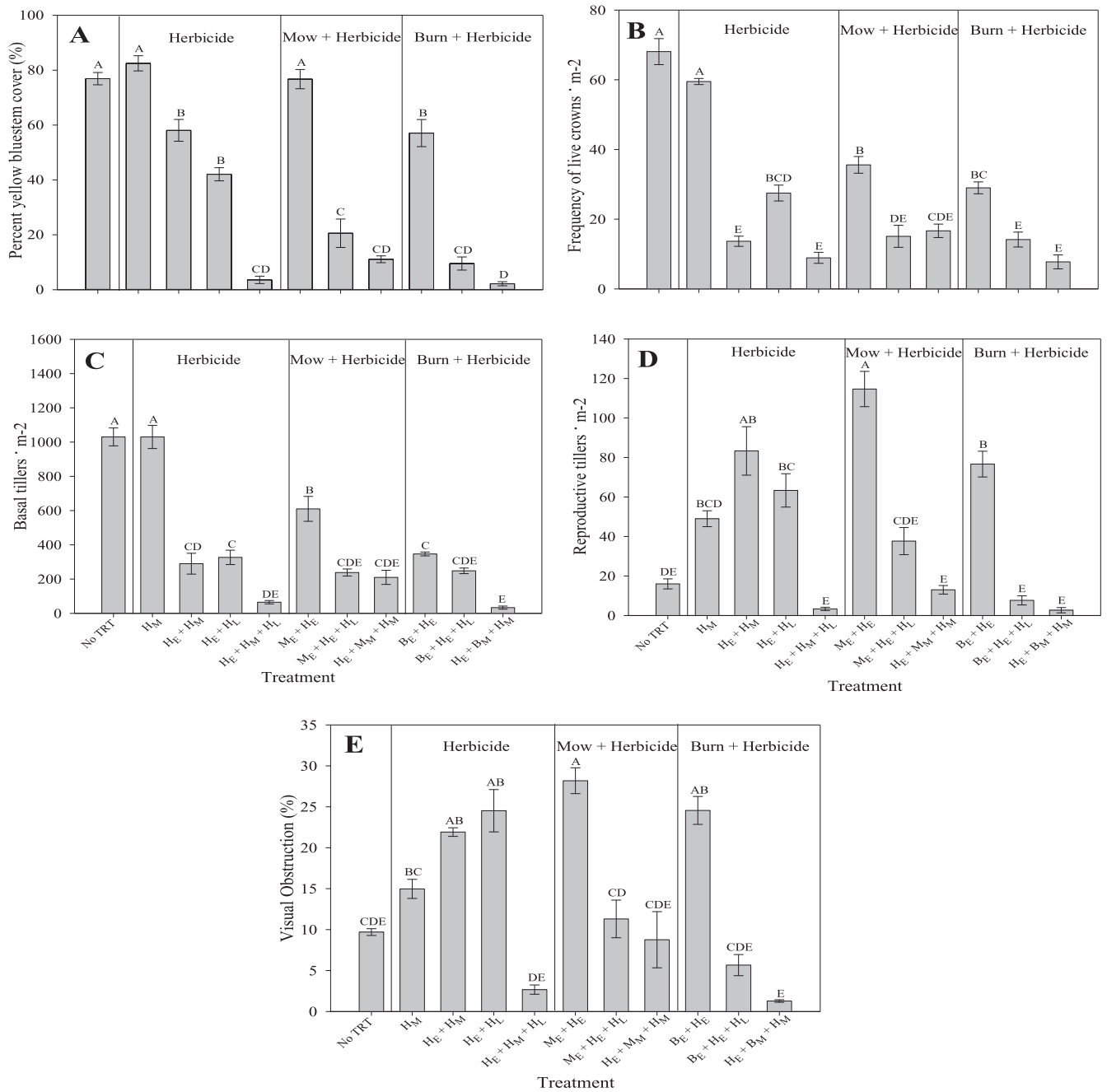

Figure 2. Yellow bluestem A, percent cover; B, frequency of live crowns (per $\left.\mathrm{m}^{2}\right)$; C, basal tiller density $\left(\right.$ per $\left.\mathrm{m}^{2}\right)$; D, reproductive tiller density $\left(\right.$ per $\mathrm{m}^{2}$ ); and $\mathbf{E}$, visual obstruction, at end of season 2008 (mean $\pm \mathrm{SE}$ ). Different letters indicate significant difference at $P<0.05$. Eleven different treatment combinations involving herbicide $(\mathrm{H})$, burning $(\mathrm{B})$, and mowing $(\mathrm{M})$ were applied in 2007 either once, twice, or three times during the growing season: early (subscript $E=18$ May), middle ( $M=2$ August), late ( $L=1$ September).

Treatments that combined herbicide applications with mowing or burning were sprayed when regrowth of yellow bluestem was at an earlier growth stage than in the two herbicide application treatments $\left(\mathrm{H}_{\mathrm{E}}+\mathrm{H}_{\mathrm{M}}\right.$ and $\left.\mathrm{H}_{\mathrm{E}}+\mathrm{H}_{\mathrm{L}}\right)$ that were sprayed $>10$ wk after the first herbicide applications. Glyphosate is more readily absorbed by new growth of plants (Camacho and Moshier 1991). The combined burn and herbicide treatments consistently provided slightly greater control of yellow bluestem compared with the combined mow and herbicide treatments, possibly due to fire removing a greater amount of standing dead and upper canopy than mowing.

Surprisingly, mowing or burning in combination with a single herbicide application $\left(\mathrm{M}_{\mathrm{E}}+\mathrm{H}_{\mathrm{E}}\right.$ and $\left.\mathrm{B}_{\mathrm{E}}+\mathrm{H}_{\mathrm{E}}\right)$, as well as both double herbicide only $\left(\mathrm{H}_{\mathrm{E}}+\mathrm{H}_{\mathrm{M}}\right.$ and $\left.\mathrm{H}_{\mathrm{E}}+\mathrm{H}_{\mathrm{L}}\right)$ treatments, resulted in 4-7 times more reproductive tillers and 2-3 times greater percent visual obstruction relative to the no treatment control and the treatments combining mowing or burning with two herbicide applications $\left(\mathrm{M}_{\mathrm{E}}+\mathrm{H}_{\mathrm{E}}+\mathrm{H}_{\mathrm{L}}, \mathrm{H}_{\mathrm{E}}+\mathrm{M}_{\mathrm{M}}+\mathrm{H}_{\mathrm{M}}\right.$, $\mathrm{B}_{\mathrm{E}}+\mathrm{H}_{\mathrm{E}}+\mathrm{H}_{\mathrm{L}}$ and $\mathrm{H}_{\mathrm{E}}+\mathrm{B}_{\mathrm{M}}+\mathrm{H}_{\mathrm{M}}$; Figs. 2D, 2E, and 3B). This may have occurred due to intraspecific competitive release because yellow bluestem is very competitive with itself and aggressively resprouts (Schmidt et al. 2008). Surviving yellow bluestem plants in the double herbicide only treatments were vigorous enough to take advantage of the low conspecific density and thus were able to grow taller and produce more reproductive tillers compared with plants in the untreated control (Figs. 2 and 3), which could increase the seed bank of yellow bluestem and pose problematic for long-term control efforts (Rinella et al. 2009).

Control of exotic grasses is frequently complicated by herbicide resistance, copious seed production, persistent seed banks, and competitive advantages over native plants (Milton 2004), as well as the economic costs associated with control. With the exception of the triple herbicide treatment, combining mechanical and chemical treatments resulted in a greater reduction in cover of yellow bluestem relative to separately applying mechanical or chemical treatments. Independently, mowing, burning, and two glyphosate applications were not effective at controlling yellow bluestem. All treatments with 


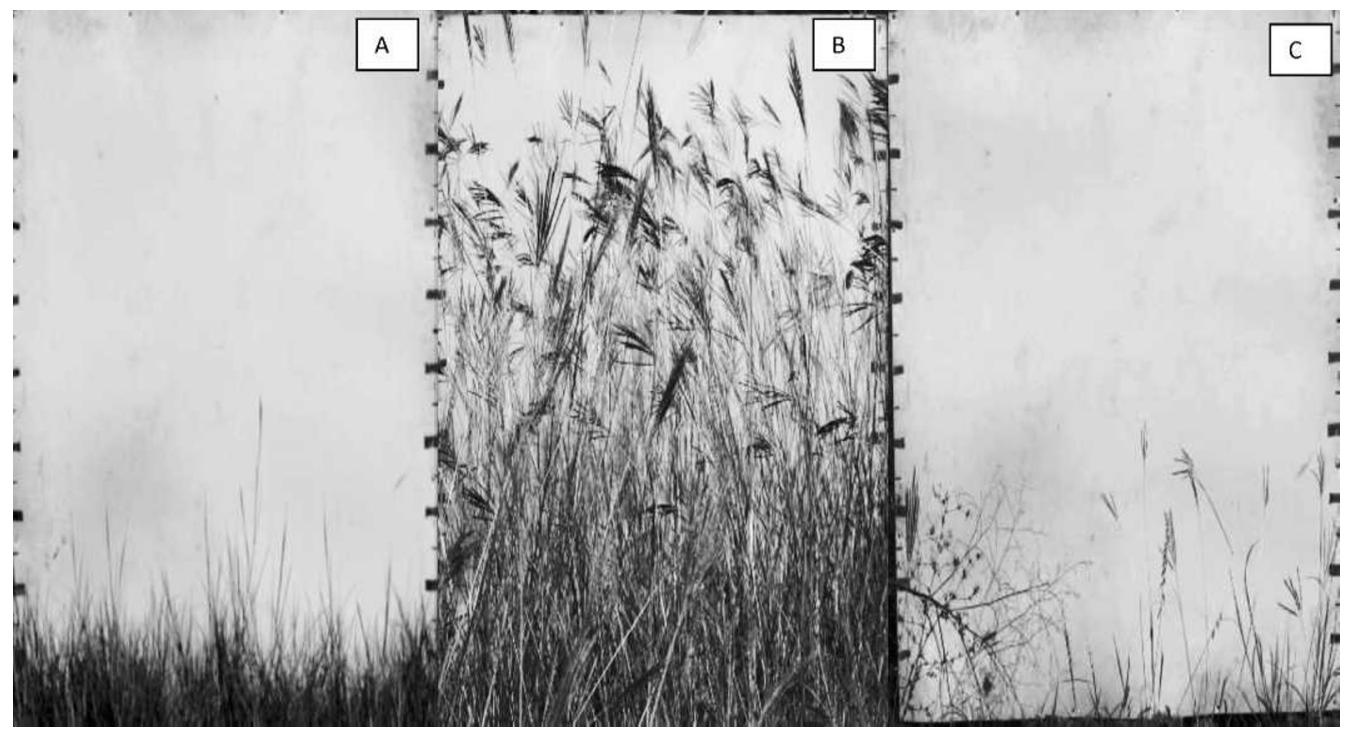

Figure 3. Visual obstruction photos of yellow bluestem plots from selected treatments, $\mathbf{A}$, control (no herbicide, burning or mowing) treatment; $\mathbf{B}$, double herbicide applications applied at the early and middle timings $\left(\mathrm{H}_{E}+\mathrm{H}_{M}\right)$; and $\mathbf{C}$, early burn followed by an herbicide application 4 wk after the burn and an additional herbicide application applied late in the season $\left(B_{E}+H_{E}+H_{L}\right)$. Note the increased number of reproductive tillers of yellow bluestem following two herbicide applications relative to the control.

mowing or burning and double herbicide applications resulted in greater control of yellow bluestem the year following treatment and were no different than applying three applications of glyphosate, which was probably due to prior mowing or burning that decreased biomass standing dead material, reduced plant structure, and improved regrowth of young, established plants. While our results did not assess the management costs associated with the various control practices, they do extend previous research, suggesting that a combination of mechanical and chemical treatments can improve control of perennial invasive weedy species (Renz and DiTomaso 2004; Adams and Galatowitsch 2006) and might be a useful management consideration when additional herbicide use is not desirable.

\section{MANAGEMENT IMPLICATIONS}

Controlling the spread of yellow bluestems in native systems is challenging because they are well adapted to the Great Plains and are physiologically similar to many native warm-season grasses of tallgrass and mixed-grass rangelands (Coyne and Bradford 1986). The moderate success of herbicide and other management tool combinations used as treatments in this experiment emphasize that integrated approaches to weed management can be as effective as herbicides alone in controlling yellow bluestem. These integrated approaches may not eradicate yellow bluestem, but may aid in reducing the size of yellow bluestem patches. However, herbicides that may injure or control yellow bluestem also may injure desirable native species (Harmoney et al. 2007). Patches where yellow bluestem has been controlled will likely have reduced native plant composition from herbicide use and from yellow bluestem competition and may require reclamation of native desirable species.

\section{ACKNOWLEDGMENTS}

We thank K. Nelson, C. Worthington. K. Parsons, K. Cothren, J. Worthington, K. Spears, and C. Walden for assistance with field work. K. Owens and C. Dunn provided helpful assistance with figures. We also thank G. Wlson and two anonymous reviewers for comments on earlier versions of the manuscript.

\section{LITERATURE CITED}

Adams, C. R., and S. M. Galatowitsch. 2006. Increasing the effectiveness of reed canary grass (Phalaris arundinacea L.) control in wet meadow restorations. Restoration Ecology 14:441-451.

Brock, F. V., K. C. Crawford, R. L. Elliott, G. W. Cuperus, S. J. Stadler, H. L. Johnson, AND M. D. Ellts. 1995. The Oklahoma mesonet-a technical overview. Journal of Atmospheric and Oceanic Technology 12:5-19.

Camacho, R. F., and L. J. Moshier. 1991. Absorption, translocation, and activity of Cga136872, Dpx-V9360, and glyphosate in rhizome johnsongrass (Sorghum halepense). Weed Science 39:354-357.

CoYNe, P. I., AND J. A. BRAdFord. 1986. Biomass partitioning in 'Caucasian' and 'WWSpar' old world bluestems. Journal of Range Management 39:303-310.

DaubenmiRE, R. F. 1959. A canopy-coverage method of vegetational analysis. Northwest Science 33:43-66.

DiTomaso, J. M., M. L. Brooks, E. B. Allen, R. Minnich, P. M. Rice, and G. B. Kyser. 2006. Control of invasive weeds with prescribed burning. Weed Technology 20:535-548.

GabBaRd, B. L., AND N. L. Fowler. 2007. Wide ecological amplitude of a diversityreducing invasive grass. Biological Invasions 9:149-160.

Harmoney, K. R., P. W. Stahlman, and K. R. Hickman. 2004. Herbicide effects on established yellow old world bluestem (Bothriochloa ischaemum). Weed Technology 18:545-550.

Harmoney, K. R., P. W. Stahlman, and K. R. Hickman. 2007. Suppression of Caucasian old world bluestem by split applications of herbicides. Weed Technology 21:545550.

Hickman, K. R., G. H. Farley, R. Channell, and J. E. Steler. 2007. Effects of old world bluestem (Bothriochloa ischaemum) on food availability and avian community composition within the mixed-grass prairie. Southwestern Naturalist 51:524530 . 
Kamler, J. F., W. B. Ballard, E. B. Fish, P. R. Lemons, K. Mote, and C. C. Perchellet. 2003. Habitat use, home ranges, and survival of swift foxes in a fragmented landscape: conservation implications. Journal of Mammalogy 84:989-995.

Limb, R. F., K. R. Hickman, D. M. Engle, J. E. Norland, and S. D. Fuhlendorf. 2007. Digital photography: reduced investigator variation in visual obstruction measurements for southern tallgrass prairie. Rangeland Ecology \& Management 60:548-552.

McWhorter, C. G., and J. E. Hanks. 1993. Effect of spray volume and pressure on postemergence johnsongrass (Sorghum halepense) control. Weed Technology 7:304-310.

Mıton, S. J. 2004. Grasses as invasive alien plants in South Africa. South African Journal of Science 100:69-75.

Packard, S., And C. F. Mutel. 2005. The tallgrass restoration handbook: for prairies, savannas, and woodlands. Washington, DC, USA: Island Press. 495 p.

RelyeA, R. A. 2012. New effects of Roundup on amphibians: predators reduce herbicide mortality; herbicides induce antipredator morphology. Ecological Applications 22:634-647.

Renz, M. J., AND J. M. DiTomaso. 2004. Mechanism for the enhanced effect of mowing followed by glyphosate application to resprouts of perennial pepperweed (Lepidium latifolium). Weed Science 52:14-23.
Rinella, M. J., B. D. Maxwell, P. K. Fay, T. Weaver, and R. L. Sheley. 2009. Control effort exacerbates invasive-species problem. Ecological Applications 19:155162.

Sammon, J. G., and K. T. Wikkins. 2005. Effects of an invasive grass (Bothriochloa ischaemum) on a grassland rodent community. Texas Journal of Science $57: 371-382$

SAS InStITUTE. 2003. SAS version 9.1 for Windows. Cary, NC, USA: SAS Institute.

Schmidt, C. D., K. R. Hickman, R. Channell, K. Harmoney, and W. Stark. 2008. Competitive abilities of native grasses and non-native (Bothriochloa spp.) grasses. Plant Ecology 197:69-80.

Simmons, M. T., S. Windhager, P. Power, J. Lott, R. K. Lyons, and C. Schwope. 2007. Selective and non-selective control of invasive plants: the short-term effects of growing-season prescribed fire, herbicide, and mowing in two Texas prairies. Restoration Ecology 15:662-669.

WeIR, J. 2009. Conducting prescribed fires: a comprehensive manual. College Station, TX, USA: Texas A\&M University Press. 194 pp.

Wolf, T. M., S. K. Harrison, F. R. Hall, and J. Cooper. 2000. Optimizing postemergence herbicide deposition and efficacy through application variables in no-till systems. Weed Science 48:761-768. 